\title{
Determination of Chromium(VI) Reduction by Acinetobacter haemolyticus using X-ray Absorption Fine Structure Spectroscopy
}

\author{
Quek Hsiao Pei ${ }^{1}$, Shafinaz Shahir ${ }^{2}$, Liu Tao ${ }^{3}$ and Wan Azlina Ahmad ${ }^{1, *}$ \\ ${ }^{1}$ Chemistry Department, Faculty of Science, Universiti Teknologi Malaysia, 81310 UTM Skudai, Johor, Malaysia \\ ${ }^{2}$ Biological Sciences Department, Faculty of Biosciences and Bioengineering, Universiti Teknologi Malaysia, 81310 UTM \\ Skudai, Johor, Malaysia \\ ${ }^{3}$ Singapore Synchrotron Light Source, National University of Singapore, 5 Research Link, Singapore 117603 \\ * Author to whom correspondence should be addressed; E-mail: azlina@kimia.fs.utm.my
}

Received: 9 November 2008

http://dx.doi.org/10.11113/mjfas.v4n2.50

\section{ABSTRACT}

Several types of microorganisms have been reported to reduce $\mathrm{Cr}(\mathrm{VI})$ to the less toxic $\mathrm{Cr}$ (III) via enzymatic reactions. The main purpose of this study is to determine the reduction of $\mathrm{Cr}(\mathrm{VI})$ by a locally isolated bacterium, Acinetobacter haemolyticus ( $A$. haemolyticus) using the x-ray absorption fine structure (XAFS) spectroscopy. XAFS analysis consisted of both the $x$-ray absorption near-edge structure (XANES) and extended x-ray absorption fine structure (EXAFS) spectra. XANES spectra of the rinsed $\mathrm{Cr}(\mathrm{VI})$-laden $A$. haemolyticus biomass indicated that chromium was only present in the form of $\mathrm{Cr}$ (III). The nearest atoms coordinated to $\mathrm{Cr}$ (III) were oxygens in an octahedral geometry. The longer $\mathrm{Cr}-\mathrm{O}$ bond lengths ( 1.97 $\mathrm{A}$ ) obtained from the EXAFS spectra corroborated the presence of chromium as $\mathrm{Cr}(\mathrm{III})$ bonded to oxygen. These findings demonstrate the ability of $A$. haemolyticus to reduce $\mathrm{Cr}(\mathrm{VI})$ to $\mathrm{Cr}(\mathrm{III})$ that was bound to oxygen atoms of the ligands in $A$. haemolyticus.

| x-ray | EXAFS | XANES | chromium | reduction | Acinetobacter |

\section{Introduction}

Wastewaters containing $\mathrm{Cr}(\mathrm{VI})$ is generated in many industrials processes, including leather-tanning, chrome-plating, stainless steel-welding, pigment production and nuclear weapons generation [1]. However, due to leakage, poor storage, and improper disposal, $\mathrm{Cr}(\mathrm{VI})$ has become one of the most frequently detected contaminant at the waste sites [2]. $\mathrm{Cr}(\mathrm{VI})$ compounds are in general more toxic than $\mathrm{Cr}$ (III) compounds due to the stronger oxidizing power [3, 4]. From a biological perspective, $\mathrm{Cr}(\mathrm{III})$ compounds have very low solubility, thus, restricting their spread and their biological availability [1].

Detoxification of $\mathrm{Cr}(\mathrm{VI})$ via reduction of $\mathrm{Cr}(\mathrm{VI})$ to $\mathrm{Cr}(\mathrm{III})$ can be carried out via chemical or biological methods. Conventional methods for the treatment of chromate include chemical reduction by using a reducing agent such as sodium sulfite, and adsorption on the ion exchange and chelating resins. However, these methods consume high amounts of energy and large quantities of chemical reagents which is not economically feasible. 
Furthermore, the resultant metal-containing chemical sludge can be a potential source of metal pollution. On the other hand, microbiological detoxification of polluted water is economical, safe, and sustainable [5, 6]. Thus, there is growing interest in the use of microorganisms for reduction of $\mathrm{Cr}$ (VI) to $\mathrm{Cr}$ (III) [7].

Bioreduction of $\mathrm{Cr}(\mathrm{VI})$ can occur directly as a result of microbial metabolism (enzymatic) or indirectly, mediated by a bacterial metabolite (such as $\mathrm{H}_{2} \mathrm{~S}$ ) [8]. Examples of such bacteria are Bacillus sp. [9], Pseudomonas putida, Escherichia coli [10], Nesterenkonia sp. strain MF2 [11], Brucella sp. [12], and Providencia sp. [2].

Previously, XAFS has been used to address metal speciation in Bacillus subtilis to determine the cell wall functional groups responsible for the absorption of $\mathrm{UO}_{2}$ at different $\mathrm{pH}$ [13]. In another study, XAFS was used for the determination of the oxidation states and chemical environments of copper species in the whole cell and peptidoglycan samples of Cyanobacterium Anabaena flos-aquae [14]. Chromium biosorption on Ecklonia sp. [15] and $\mathrm{Au}(\mathrm{III})$ reduction and binding on hop biomass [16] were also studied using XAFS.

In this study, XAFS spectroscopy was used to provide direct evidence of the reduced $\mathrm{Cr}$ deposited in $A$. haemolyticus. XANES provides information on the final oxidation state of $\mathrm{Cr}$ in $A$. haemolyticus from the reduction of $\mathrm{Cr}(\mathrm{VI})$ and EXAFS provides information on the coordination environment such as the nearest neighbouring atoms.

\section{Materials and Methods}

\subsection{Bacterial strain}

Acinetobacter haemolyticus (GenBank accession number EF369508) was used throughout this study. Acinetobacter is a Gram-negative, strictly aerobic, oxidase-negative, non-motile coccobacilli genus. The colonies formed were circular, convex, smooth and translucent with entire margins [17].

\subsection{XAFS sample preparation}

Active culture of $A$. haemolyticus $(10 \%$, v/v) was inoculated into 4 Erlenmeyer flasks containing $400 \mathrm{~mL}$ of LB broth each and incubated at $30^{\circ} \mathrm{C}$ and $200 \mathrm{rpm}$. After the culture reached mid-exponential phase, stock solutions of filter-sterilized $\mathrm{Cr}(\mathrm{VI})$ was added to give final concentration of $60 \mathrm{mg} \mathrm{L}^{-1}$. After 48 hours of incubation, the independently grown $400-\mathrm{mL}$ cultures were combined and pelleted by centrifugation at 13000 rpm for 5 minutes at $4^{\circ} \mathrm{C}$ to provide sufficient biomass for XAFS measurements and to eliminate interculture variability. The cell suspensions were then divided into 2 sets of Eppendorf tubes. One set of the cell suspensions was rinsed twice with phosphate buffered saline (10X, pH7.4) (PBS) (Fluka, Switzerland) solution to remove any unbound chromium from the samples. The bacterial suspensions obtained after rinsing with PBS were centrifuged twice to ensure maximum removal of entrained solutions. Both the samples in Eppendorf tubes were placed in flasks sealed with butyl rubber stoppers and purged with $\mathrm{N}_{2}$ gas for about 8 hours. This step was carried out to free $\mathrm{O}_{2}$ to gain an anaerobic condition, and to dry the homogeneous wet cell suspensions. To preserve the samples prior to analysis, the cell suspensions were placed in air-tight Eppendorf tubes purged with $\mathrm{N}_{2}$ gas that, in turn, was kept at low temperature $\left(4^{\circ} \mathrm{C}\right)$. For XAFS measurements, bacterial suspensions were loaded directly into a slotted sample holder, sealed with Kapton tape.

\subsection{XAFS data collection}

Cr K-edge XAFS spectra was collected at the XDD beamline (Oxford Instruments), Singapore Synchrotron Light Source (SSLS), operated at electron energy, $0.7 \mathrm{GeV}$ and beam current $200 \mathrm{~mA}$. The bacterial suspensions 
were measured in fluorescence mode at room temperature using a Lytle-type fluorescence detector. The reference $\mathrm{Cr}$ metal foil and compounds were measured using transmission mode. The references used were $\mathrm{Cr}$ foil, $\mathrm{Cr}\left(\mathrm{NO}_{3}\right)_{3}, \mathrm{Cr}\left(\mathrm{NO}_{3}\right)_{3}(\mathrm{aq}), \mathrm{CrOOH}, \mathrm{Cr}$-acetate, and $\mathrm{K}_{2} \mathrm{Cr}_{2} \mathrm{O}_{7}$. A channel-cut silicon (111) double-crystal monochromator with an entrance slit of $1 \mathrm{~mm}$ was used for all XAFS measurements. Energy calibration was carried out using $\mathrm{Cr}$ foil. For adsorption samples, multiple scans were collected and averaged to improve signal to noise ratio.

\subsection{XAFS data analysis}

Data analysis was carried out using WINXAS 2.3 [18]. Background subtractions were performed by applying linear and polynomial fits to pre- and post-edge regions, respectively. The spectra were then converted into $\mathrm{k}$ space (wave vector space $\AA^{-1}$ ) from $\mathrm{E}$ space. The conversion to $\mathrm{k}$ space was based on the energy of the photoelectrons ejected from the samples. The EXAFS were extracted after background correction using a spline of seven knots taken between $2.0 \AA^{-1}$ and $12.2 \AA^{-1}$. The spectra were then $\mathrm{k}^{3}$ weighted and Fourier transformed into $\mathrm{R}$ space. The same procedures were applied to reference samples. The phase shift and backscattering amplitude were theoretically calculated from CrOOH using FEFF6 and s2 was determined to be 0.82 by fitting $\mathrm{CrOOH}$ and was fixed during the fit to other spectra. The input files for the FEFF6 fitting were created using the Atoms software and crystallographic data in the literature. The interatomic distances $(\mathrm{R})$, coordination numbers $(\mathrm{CN})$, and Debye-Waller factors $\left(\sigma^{2}\right)$ on the first coordination shell were obtained by fitting to the first peak in Fourier transform.

\section{Results and Discussion}

The XANES spectra of $\mathrm{Cr}$ in A. haemolyticus cells, together with the XANES spectra of the reference compounds of $\mathrm{Cr}$ metal foil, Cr-acetate, $\mathrm{Cr}\left(\mathrm{NO}_{3}\right)_{3}, \mathrm{Cr}\left(\mathrm{NO}_{3}\right)_{3}(\mathrm{aq})$ and $\mathrm{K}_{2} \mathrm{Cr}_{2} \mathrm{O}_{7}$ are shown in Figure 1.

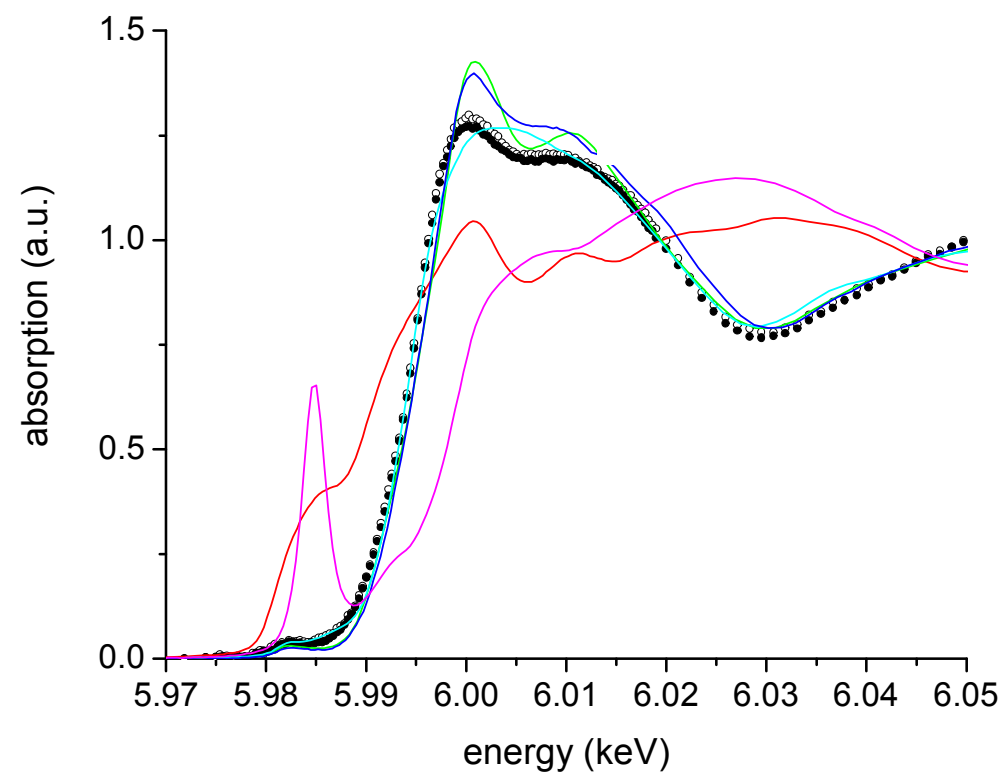

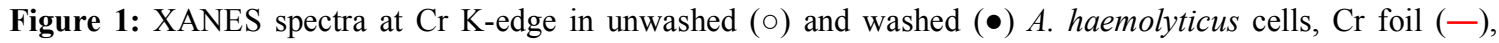
$\mathrm{Cr}\left(\mathrm{NO}_{3}\right)_{3}(-), \mathrm{Cr}\left(\mathrm{NO}_{3}\right)_{3}(\mathrm{aq})(-)$, Cr-acetate $(-)$, and $\mathrm{K}_{2} \mathrm{Cr}_{2} \mathrm{O}_{7}(-)$ standards. 
A similar finding was obtained by Park et al. [15], where the XANES data for $\mathrm{Cr}(\mathrm{VI})$ reference, $\mathrm{K}_{2} \mathrm{Cr}_{2} \mathrm{O}_{7}$ shows a well-defined $\mathrm{Cr}(\mathrm{VI})$ pre-edge peak at $5.984 \mathrm{keV}$ (Figure 1). The pre-edge peak is attributed to the electron transition from $\mathrm{Cr} 1 \mathrm{~s}$ orbital to $3 \mathrm{~d}$ [19]. The lack of the pre-edge feature for any of the other reference compounds indicates that the chromium was in its reduced valence state, $\mathrm{Cr}$ (III). As seen in the XANES spectra, various $\mathrm{Cr}$ reference compounds with different oxidation states are distinguishable from each other. The small pre-edge feature for $\mathrm{Cr}$ (III) compounds is indicative of $\mathrm{Cr}$ (III) bound to oxygen ligands in an octahedral arrangement of atoms. As reported in [19], the pre-edge features are present for octahedral $\mathrm{Cr}(\mathrm{III})$ at 5990.5 and $5993.5 \mathrm{eV}$ due to $1 \mathrm{~s}$ to $3 \mathrm{~d}\left(\mathrm{t}_{2 \mathrm{~g}}\right)$ and $1 \mathrm{~s}$ to $3 \mathrm{~d}\left(\mathrm{e}_{\mathrm{g}}\right)$ electronic transitions, respectively.

The results presented in Figure 1 indicate that the XANES spectra of the bacterial biomass were identical to that of the $\mathrm{Cr}$ (III) reference compounds and the absence of a well-defined pre-edge peak at $5.984 \mathrm{keV}$ and the chemical shift demonstrate that only octahedral-coordinated $\mathrm{Cr}$ (III) existed in the A. haemolyticus cells. Both bacterial biomass (washed and unwashed) showed no evidence of an absorption peak for $\mathrm{Cr}(\mathrm{VI})$ from the starting $\mathrm{K}_{2} \mathrm{Cr}_{2} \mathrm{O}_{7}$ result in the growth medium. The $\mathrm{Cr}$ in the bacterial biomass also did not correlate to the spectrum of $\mathrm{Cr}$ metal foil. They are similar to $\mathrm{Cr}$-acetate. Based on the results obtained, XANES was successfully employed to determine the oxidation state of $\mathrm{Cr}$ in A. haemolyticus cells after growth in LB broth supplemented with $60 \mathrm{mg} \mathrm{L}^{-}$ ${ }^{1}$ of $\mathrm{Cr}(\mathrm{VI})$. The reduction in the oxidation state of $\mathrm{Cr}(\mathrm{VI})$ reacted with biomass has been previously observed in the Cr K-edge XANES for a number of different biomaterials such as hops [20], native microbial community [21], saltbush (Atriplex canescens) [22], and brown seaweed (Ecklonia) [15]. Interestingly, the washed and unwashed $A$. haemolyticus biomass appeared to be similar and thus, reflecting the strong adsorption/absorption of $\mathrm{Cr}$ onto the cell surface or intracellularly despite washes with PBS buffer which served to strip any adventitiously bound $\mathrm{Cr}$ ions.

The pre-edge of the biomass and reference compounds in Figure 1 was enlarged as shown in Figure 2. The geometry of the complex formed between $\mathrm{Cr}(\mathrm{III})$ and bacterial cells can be determined if identical or very similar to that of one of the model compounds.

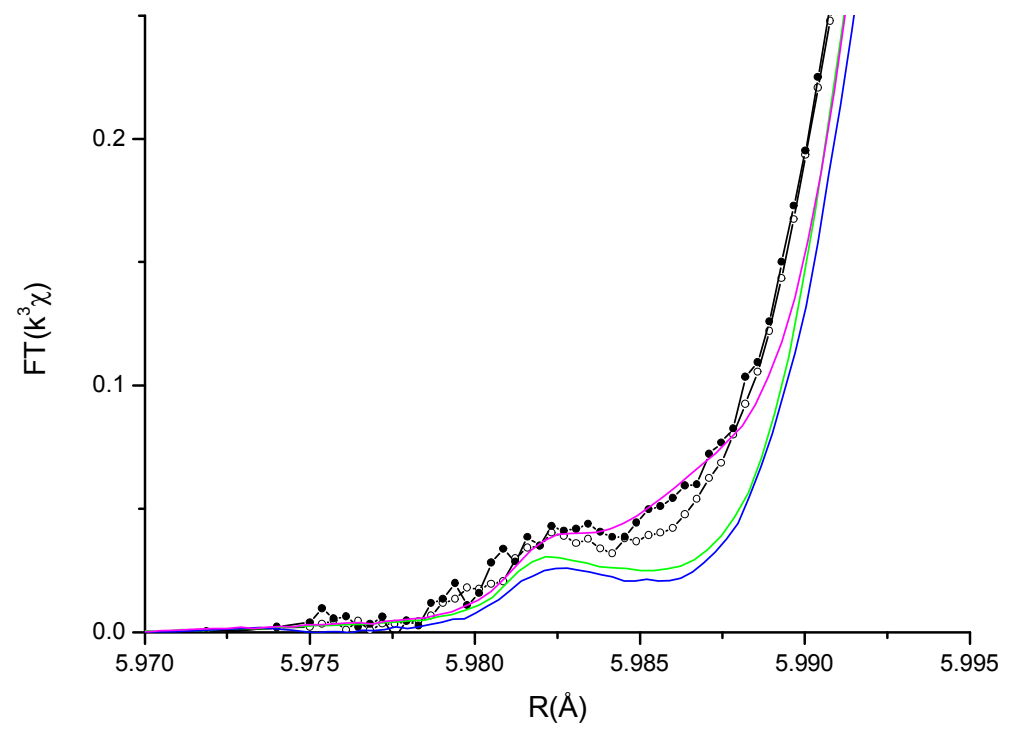

Figure 2: Pre-edge spectra of XANES at Cr K-edge in unwashed (०) and washed $(\bullet)$ A. haemolyticus cells, $\mathrm{Cr}\left(\mathrm{NO}_{3}\right)_{3}(-), \mathrm{Cr}\left(\mathrm{NO}_{3}\right)_{3}(\mathrm{aq})(-)$, and Cr-acetate $(-)$ standards. 
The spectra of $\mathrm{Cr}$ in the A. haemolyticus biomass closely matched that of Cr-acetate showing their almost similar molecular geometries. Cr-acetate has multi-nuclear geometry in aqueous solution; the nearest neighbours for $\mathrm{Cr}(\mathrm{III})$ are 5 oxygen atoms either from acetate $\left(\mathrm{COO}^{-}\right)$or from water molecules. $\mathrm{Cr}$-O bonds in $\mathrm{Cr}$-acetate have 5 different lengths. Therefore, the structure may be in an octahedral or pentahedral arrangement. At this local structure, the pre-edge peak show a slight enhanced intensity compared to the octahedrally coordinated geometry in $\mathrm{Cr}\left(\mathrm{NO}_{3}\right)_{3}$ and $\mathrm{Cr}\left(\mathrm{NO}_{3}\right)_{3}$ (aq) [23]. The pre-edge spectra of the reference compounds, $\mathrm{Cr}\left(\mathrm{NO}_{3}\right)_{3}$ was different from those of the A. haemolyticus biomass and $\mathrm{Cr}$-acetate. This implies that the $\mathrm{Cr}$ was not bound to the nitrogen atom of amino and nitrile groups [15]. The $\mathrm{Cr}$ in $\mathrm{Cr}\left(\mathrm{NO}_{3}\right)_{3} .4 \mathrm{H}_{2} \mathrm{O}$ in aqueous state complexes with $\mathrm{H}_{2} \mathrm{O}$ and $\mathrm{NO}_{3}$ as neighbours to form highly symmetrical complexes. The difference in the spectra indicates that the $\mathrm{Cr}$ (III) complexes formed in the biomass are in a non-centro-symmetric geometry.

Figure 3 shows the Fourier-transformed EXAFS (FT-EXAFS) spectra of the Cr reference compounds as well as the A. haemolyticus biomass to determine the neighbouring atoms of $\mathrm{Cr}(\mathrm{III})$ in $A$. haemolyticus biomass. The FT spectra for adsorbed samples show one dominant peak from $\mathrm{Cr}-\mathrm{O}$ coordination. The lack of the high order coordination peaks is an indication that $\mathrm{Cr}$ are very dispersive in the samples, similar to an amorphous state for $\mathrm{Cr}$. The FT spectra for the biomass were also almost similar to Cr-acetate which corroborates the result (Figure 2) mentioned earlier that $\mathrm{Cr}$ (III) was bound to oxygen ligands [23].

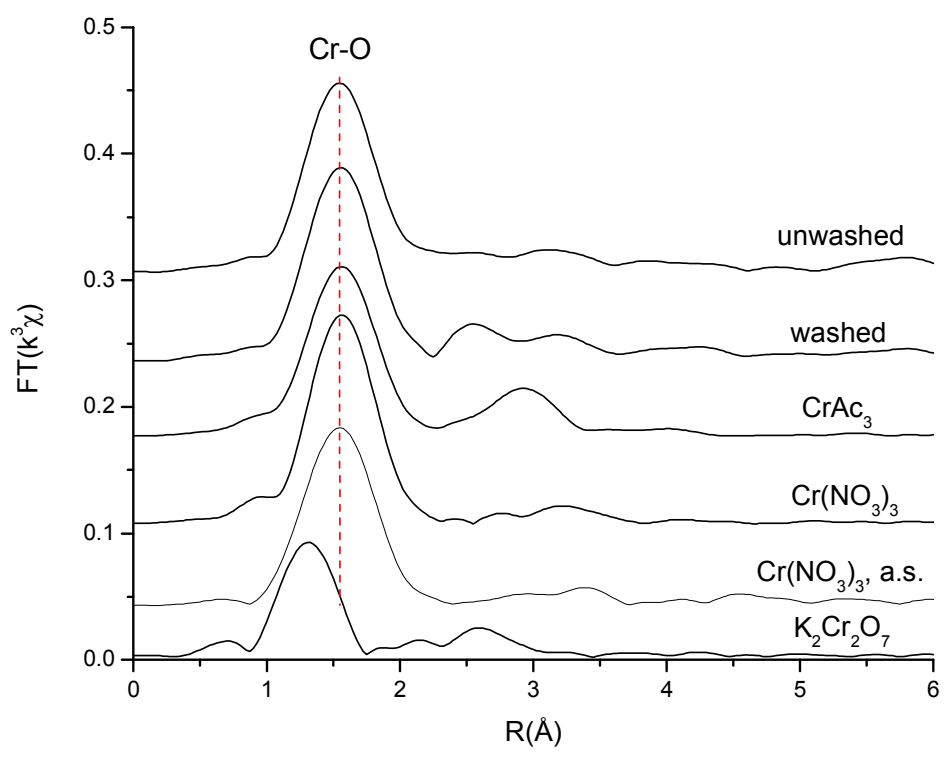

Figure 3: Fourier-transform spectra of $\mathrm{Cr}$ in unwashed and washed A. haemolyticus cells, $\mathrm{Cr}$-acetate, $\mathrm{Cr}\left(\mathrm{NO}_{3}\right)_{3}$, $\mathrm{Cr}\left(\mathrm{NO}_{3}\right)_{3}(\mathrm{aq})$, and $\mathrm{K}_{2} \mathrm{Cr}_{2} \mathrm{O}_{7}$ standards. 


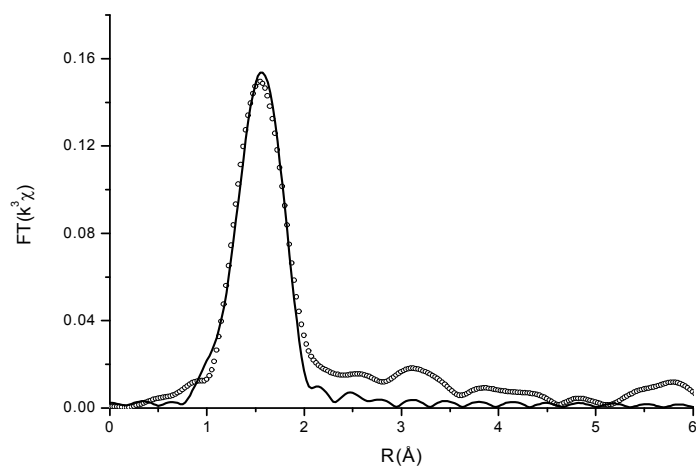

(a)

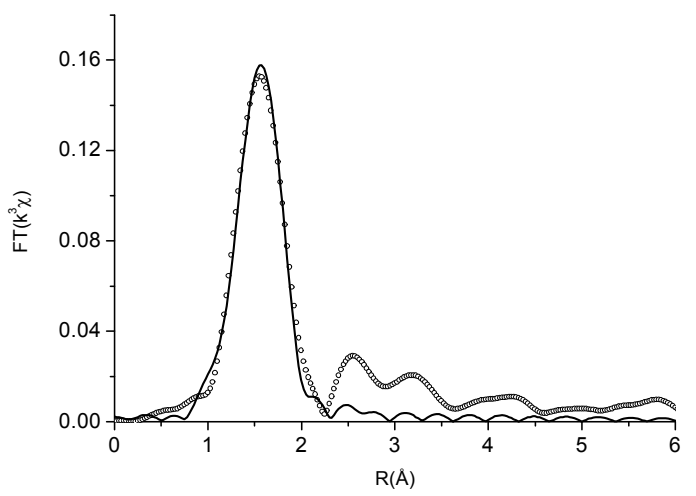

(b)

Figure 4: One shell fittings of the Fourier transforms of EXAFS of the $\mathrm{Cr}$ in (a) unwashed, and (b) washed $A$. haemolyticus cells (०) with $\mathrm{Cr}-\mathrm{O}(-)$.

Figure 4 demonstrates that the first-shell peak of each sample is satisfactorily fitted. The $\mathrm{Cr}-\mathrm{O}$ distance were approximately the same (Table 1) in the biomass and $\mathrm{Cr}(\mathrm{III})$ reference compounds; $1.98 \AA$ for both $\mathrm{Cr}$ (III) reference compounds $\left(\mathrm{Cr}\left(\mathrm{NO}_{3}\right)_{3} \cdot 4 \mathrm{H}_{2} \mathrm{O}\right.$ and $\mathrm{Cr}$-acetate) whereas, 1.97-1.98 $\AA$ for the washed and unwashed biomass. The longer $\mathrm{Cr}-\mathrm{O}$ interatomic distance in the biomass than in $\mathrm{K}_{2} \mathrm{Cr}_{2} \mathrm{O}_{7}$ reveals that the $\mathrm{Cr}$ in these samples is in the form of $\mathrm{Cr}(\mathrm{III})$. The fact that the oxidation state associated with $\mathrm{Cr}(\mathrm{VI})$ is greater than that with $\mathrm{Cr}$ (III) results in the shorter first-shell interatomic distance because of the stronger attractive force between $\mathrm{Cr}(\mathrm{VI})$ and its neighbouring oxygen [24]. The interatomic distance of $\mathrm{Cr}(\mathrm{III})$ and oxygen reported are between 1.96-1.99 $\AA[15,20,23]$ whereas for $\mathrm{Cr}(\mathrm{VI})$ and oxygen are between 1.64-1.67 [20, 22, 24].

Table 1 also shows the $\mathrm{CN}$ of the $\mathrm{Cr}(\mathrm{III})$ bound to the bacterial biomass that are almost similar to that of the reference compounds. In a study using hops biomass, the $\mathrm{CN}$ may be determined by the availability or the orientation of the free oxygen ligands on the biomass [20]. The orientation and availability of free oxygen atoms on the biomass may also slightly change the geometry of the complex formed. The $\mathrm{CN}$ values support an octahedral coordination of $\mathrm{Cr}-\mathrm{O}$ in adsorbed samples. However, these $\mathrm{Cr}-\mathrm{O}$ bonds are dispersive and very different from the perfect octahedral geometry. Their spatial configurations are not as perfect as the octahedral geometry in $\mathrm{Cr}\left(\mathrm{NO}_{3}\right)_{3}$. It is therefore deduced that $\mathrm{Cr}-\mathrm{O}$ in the biomass with $\mathrm{Cr}$ may be partially from water molecules and partially from ligands of biomass.

Table 1: Fitting results in A. haemolyticus grown in LB broth with $60 \mathrm{mg} \mathrm{L}^{-1}$ of $\mathrm{Cr}(\mathrm{VI})$ and reference compounds.

\begin{tabular}{|l|c|c|c|c|}
\hline \multicolumn{1}{|c|}{ Sample } & Bond & $\mathbf{C N}^{\mathrm{a}}$ & $\mathbf{R}(\boldsymbol{\AA})$ & $\boldsymbol{\sigma}^{\mathbf{2}}\left(\boldsymbol{\AA}^{\mathbf{2}}\right)$ \\
\hline Washed biomass & $\mathrm{Cr}-\mathrm{O}$ & 5.6 & 1.97 & 0.0018 \\
Unwashed biomass & $\mathrm{Cr}-\mathrm{O}$ & 6.0 & 1.98 & 0.0027 \\
$\mathrm{Cr}_{\mathrm{N}}$ & $\mathrm{Cr}-\mathrm{O}$ & 5.7 & 1.98 & 0.0024 \\
Cr-acetate & $\mathrm{Cr}-\mathrm{O}$ & 5.4 & 1.98 & 0.0030 \\
\hline
\end{tabular}

a $\mathrm{CN}$ represents the coordination number (number of neighbouring atoms), $\mathrm{R}$ is the interatomic distances given in angstroms, and $\sigma^{2}$ is the Debye-Waller factor given in angstroms squared. 
The longer interatomic distance of $\mathrm{Cr}-\mathrm{O}$ in Table 1 confirmed the results of the XANES analysis where only $\mathrm{Cr}(\mathrm{III})$ is present in the biomass. In addition to that, the results of the EXAFS fittings for the $\mathrm{Cr}$ (III) in the biomass also confirmed the results of the XANES analysis. This analysis proved that the $\mathrm{Cr}(\mathrm{VI})$ was not merely sorbed as $\mathrm{Cr}(\mathrm{VI})$ in $A$. haemolyticus but rather was reduced to $\mathrm{Cr}(\mathrm{III})$. The fitting results show only $\mathrm{Cr}$ (III) was present and that $\mathrm{Cr}$ (III) was neighbouring with oxygen ligands. The similarity of the biomass spectra to $\mathrm{Cr}$ acetate spectra indicates that the $\mathrm{Cr}(\mathrm{III})$ was bound to more oxygen from bacteria than $\mathrm{H}_{2} \mathrm{O}$ as in the case of $\mathrm{Cr}$ acetate. Since the XAFS analysis suggests that the neighbouring atoms of $\mathrm{Cr}$ (III) is $\mathrm{O}$ and that $\mathrm{Cr}(\mathrm{III})$ coordinates less with $\mathrm{H}_{2} \mathrm{O}$, it is suggested that $\mathrm{Cr}(\mathrm{III})$ formed complexes more with the carboxyl ( $\mathrm{COO}^{-}$) group from $A$. haemolyticus. However, the XAFS spectrum taken from a sample reflects the average local environment of all probed atoms in it [25]. Thus, to be able to separate, identify, and quantify the binding mechanism of $\mathrm{Cr}$ in the multiple binding-site case of the biomass requires a clear understanding of the isolated contributions in the spectra from all potential ligands (intra and extracellularly).

\section{Conclusion}

In conclusion, XAFS was successfully employed for the study of $\mathrm{Cr}$ in A. haemolyticus. $\mathrm{Cr}$ in the form of $\mathrm{Cr}(\mathrm{III})$ neighbouring with oxygen ligands was found in $A$. haemolyticus as a result of $\mathrm{Cr}(\mathrm{VI})$ reduction.

\section{Acknowledgements}

The authors acknowledge the Ministry of Higher Education (MOHE), Malaysia for the financial support through FRGS funding 78176 and Ministry of Science, Technology and Innovation (MOSTI), Malaysia for NSF award to Quek Hsiao Pei. Research carried out (in part) at the Singapore Synchrotron Light Source, National University of Singapore under NUS Core Support C-380-003-003-001, A*STAR/MOE RP 3979908M and A*STAR 121050038 grants.

\section{References}

[1] C. F. Gonzalez, D. F. Ackerley, C. H. Park and A. Matin, Acta Biotechnol., 23 (2003) 233-239.

[2] U. Thacker, R. Parikh, Y. Shouche and D. Madamwar, Process Biochem., 41 (2006) 1332-1337.

[3] C. Cervantes, J. Campos-García, S. Devars, F. Gutiérrez-Corona, H. Loza-Tavera, J. C. Torres-Guzmán and R. Moreno-Sánchez, FEMS Microbiol. Rev., 25 (2001) 335-347.

[4] S. A. Katz, H. Salem, The Biological and Environmental Chemistry of Chromium, VCH Publisher, Inc., United States of America, 1994.

[5] H. Eccles, Int. Biodeterior. Biodegrad., 35 (1995) 5-16.

[6] A. R. Shakoori, M. Makhdoom and R. U. Haq, Appl. Microbiol. Biotechnol., 53 (2000) 348-351.

[7] F. A. O. Camargo, B. C. Okeke, F. M. Bento and W. Y. Frankenberger, Appl. Soil Ecology, 29 (2005) 193202.

[8] C. M. Hansel, B. W. Wielinga and S. Fendorf, Geochimica et Cosmochimica Acta, 67 (2003) 401-412.

[9] R. Elangovan, S. Abhipsa, B. Rohit, P. Ligy and K. Chandraraj, Biotechnol. Letters, 28 (2006) 247-252.

[10] Y. Barak, D. F. Ackerley, C. J. Dodge, L. Banwari, C. Alex, A. J. Francis and A. Matin, Appl. Environ. Microbiol., 72 (2006) 7074-7082.

[11] M. A. Amoozegar, A. Ghasemi, M. R. Razavi and S. Naddaf, Process Biochem., 42 (2007) 1475-1479.

[12] U. Thacker, R. Parikh, Y. Shouche and D. Madamwar, Bioresour. Technol., 98 (2007) 1541-1547.

[13] S. D. Kelly, K. M. Kemner, J. B. Fein, D. A. Fowle, M. I. Boyanov, B. A. Bunker and N. Yee, Geochimica et Cosmochimica Acta 66, (2002) 3855-3871. 
[14] X. C. Kretschmer, G. Meitzner, J. L. Gardea-Torresdey and R. Webb, Appl. Environ. Microbiol., 70 (2004) 771-780

[15] D. Park, Y. Yun and J. M. Park. J. Coll. Interface Sci., 317 (2008). 54-61.

[16] M. L. López, J. G. Parsons, J. R. Peralta Videa and J. L. Gardea-Torresdey, Microchem. J., 81 (2002) 50 56.

[17] A. Nemec, L. Dijkshoorn, I. Cleenwerck, T. D. Baere, D. Janssens, T. J. K. Reijden, P. Ježek and M. Vaneechoutte, Int. J. Syst. Evol. Microbiol., 53 (2003) 1563-1567.

[18] T.Ressler, J. Phys. IV, 7 (1997) C2-269.

[19] M. Peterson, G. E. Brown, G. A. Parks and C. L. Stein, Geochimica et Cosmochimica Acta, 61 (1997) 3399-3412.

[20] J. G. Parsons, M. Hejazi, K. J. Tiemann, J. Henning and J. L. Gardea-Torresdey, Microchem. J., 71 (2002) 211-219.

[21] D. S. Oliver, F. J. Brockman, R. S. Bowman and T. L. Kieft, J. Environ. Qual., 32 (2003) 317-324.

[22] M. F. Sawalha, J. L. Gardea-Torresdey, J. G. Parsons, G. Saupe and J. R. Peralta-Videa, Microchem. J., 81 (2005) 122-132.

[23] J. L. Gardea-Torresdey, K. Dokken, K. J. Tiemann, J. G. Parsons, J. Ramos, N. E. Pingitore and G. Gamez, Microchem. J., 71 (2002) 157-166.

[24] Y. Wei, L. Hsu, H. P. Wang and K. Chen, J. Electron Spectrosc. Relat. Phenom., 156-158 (2007) 204-207.

[25] M. I. Boyanov, S. D. Kelly, K. M. Kemner, B. A. Bunker, J. B. Fein and D. A. Fowles, Geochimica et Cosmochimica Acta, 67 (2003) 3299-3311. 